\title{
PENGARUH GAJI DAN PENGAWASAN PIMPINAN TERHADAP SEMANGAT KERJA PEGAWAI HONOR PADA KANTOR DINAS DI LINGKUNGAN KABUPATEN ROKAN HILIR
}

\author{
Fitri Hidayati \\ Dosen Fakultas Ekonomi dan Ilmu Sosial \\ Universitas Islam Negeri Sultan Syarif Kasim Riau \\ email:fitrihidayati@uin-suska.ac.id
}

\begin{abstract}
Abstrak
Penelitian ini dilaksanakan pada kantor dinas di lingkungan Kabupaten Rokan Hilir. Penelitian ini membahas permasalahan dengan judul " pengaruh gaji dan pengawasan pimpinan terhadap semangat kerja pegawai honor pada kantor dinas di lingkungan Kabupaten Rokan Hilir". Permasalahan terkait dengan semangat kerja pegawai honor pada kantor dinas di lingkungan Kabupaten Rokan Hilir tersebut yang relatif masih rendah yang diduga dipengaruhi oleh rendahnya gaji pegawai honor dan pengawasan pimpinan yang belum maksimal. Jumlah populasi sebanyak 484 orang dan yang menjadi sampel sebanyak 83 orang dengan menggunakan metode random sampling. Hasil penelitian menunjukkan bahwa secara simultan gaji dan pengawasan pimpinan berpengaruh signifikan terhadap semangat kerja pegawai honor sebesar 22,4\%. Dan sisanya 77,6 \% dipengaruhi oleh variabel lain yang tidak diteliti pada penelitian ini. Pengujian secara parsial diperoleh bahwa terdapat pengaruh antara variabel gaji terhadap semangat kerja pegawai honor adalah sebesar 0,198 atau 19,8\% dengan tingkat signifikan 0,013<0,05, dan pengujian secara parsial diperoleh bahwa terdapat pengaruh antara variabel pengawasan pimpinan terhadap semangat kerja pegawai adalah sebesar 0,405 atau 40,5\% dengan tingkat signifikan 0,000 < 0,05. Untuk itu perlu disarankan kepada pimpinan daerah Kabupaten Rokan Hilir bahwa gaji yang telah diberikan kepada pegawai honor harus dipertimbangan untuk meningkatkan jumlah gaji yang diberikan dan disesuaikan dengan UMR yang berlaku, dan dari pengawasan sebaiknya pimpinan menekankan kembali fungsi-fungsi dari pengawasan sehingga pegawai memiliki kinerja yang lebih baik lagi serta penekanan pada pemberlakuan sanksi kepada pegawai yang melanggar aturan yang berlaku.
\end{abstract}

Kata Kunci : Gaji, Pengawasan Pimpinan dan Semangat Kerja.

\section{PENDAHULUAN}

Organisasi pemerintah dijalankan oleh aparatur-aparatur negara yang biasa disebut dengan pegawai negeri sipil. Selain pegawai negeri sipil saat ini banyak pula pengangkatan pegawai tetap non PNS seperti pegawai honor ataupun pegawai kontrak daerah. Sumber daya manusia sangat penting dalam menunjang kemajuan organisasi, untuk itu sudah selayaknya kinerja pegawai perlu mendapat perhatian dari pimpinan, sehingga mereka dapat melaksanakan tugas dengan sungguhsungguh dan penuh tanggung jawab serta memiliki motivasi yang tinggi. Untuk menghasilkan kinerja dan produktiivitas pegawai yang tinggi dibutuhkan semangat kerja tinggi dalam setiap usaha kerjasama pegawai untuk mencapai tujuan organisasi Sastrohadiwiryo (2008).Secara spesifik Hasibuan (2009) manyatakan semangat kerja yaitu keinginan dan kesungguhan seseorang mengerjakan pekerjaannya dengan baik serta disiplin untuk mencapai prestasi kerja yang baik.

Menurut Nawawi (1990) ada beberapa faktor yang mempengaruhi semangat kerja seseorang antara lain : 1) 
minat/ perhatian terhadap pekerjaan, 2) upah atau gaji, 3) status sosial berdasarkan jabatan, 4) tujuan yang mulia dan pengabdian, 5) suasana lingkungan kerja, 6) hubungan manusiawi yang dikembangkan, dan 7) pengawasan dari pimpinan.

Rendahnya semangat kerja pegawai merupakan permasalahan yang paling sering diperbincangkan dalam manajemen sumberdaya manusia, khususnya pada sektor publik. Dilingkungan Pemerintah Kabupaten Rokan Hilir, ada beberapa permasalahan pegawai secara umum yang penulis temukan, antara lain : 1) masih adanya pegawai yang tidak berada diruangan kantor saat jam dinas, 2) masih ada sebagian pegawai yang duduk-duduk di warung kopi saat jam dinas dan 3) masih ada pegawai yang kurang bersemangat melaksanakan pekerjaan dan hanya sekedar melepaskan tanggung jawab.

Khusus untuk pengawai honor sebagai bagian tenaga sumber daya manusia yang dipekerjakan oleh pejabat yang berwenang dan pejabat Pembina kepegawaian untuk membantu Pegawai Negeri Sipil dalam memberikan pelayanan kepada masyarakat juga menunjukkan semangat kerja yang rendah, hal tersebut dipengaruhi oleh gaji dan pengawasan pimpinan. Hal ini terlihat dari fenomena antara lain : (1) rendahnya gaji untuk pegawai honor. (2) pimpinan belum maksimal melakukan pengawasan pada pegawai yang ada didinas baik PNS maupun honor sehingga masih banyak saat jam dinas pegawai berkeliaran diluar kantor. (3) pimpinan masih belum maksimal memberikan bantuan untuk memperbaiki kekurangan yang ada terhadap pelaksanaan tugas pegawai yang bermasalah.(4) pimpinan masih belum tegas memberikan sangsi-sangsi sesuai peraturan pemerintah bagi yang melanggar kode etik dan pelaksanaan tugas serta kedisiplinan kerja.

Dari sisi kuantitas, jumlah pegawai dilingkungan Pemerintah Kabupaten Rokan Hilir lebih didominasi oleh pegawai yang memiliki status Honorer dengan SK Bupati. Hal ini dapat dilihat pada tabel 1.1 dibawah ini :

Tabel 1.1

Jumlah Pegawai pada Kantor-kantor Dinas di Lingkungan Kabupaten Rokan Hilir Tahun 2014

\begin{tabular}{|c|l|c|c|}
\hline \multirow{2}{*}{ NO } & \multirow{2}{*}{ KETERANGAN } & \multicolumn{2}{c|}{ JUMLAH PEGAWAI } \\
\cline { 3 - 4 } & & PNS & NON PNS (HONOR) \\
\hline 1 & DINAS PENDIDIKAN & 80 & 123 \\
\hline 2 & DINAS PERIKANAN & 65 & 55 \\
\hline 3 & DINAS KEPENDUDKAN DAN CATATAN SIPIL & 41 & 70 \\
\hline 4 & DINAS PENDAPATAN & 73 & 58 \\
\hline 5 & DINAS SOSIAL & 22 & 35 \\
\hline 6 & DINAS PERKEBUNAN & 40 & 40 \\
\hline 7 & DINAS PERTANIAN & 31 & 45 \\
\hline 8 & DINAS KEHUTANAN & 54 & 22 \\
\hline 9 & DINAS PARIWISATA & 20 & 36 \\
\hline & TOTAL & 426 & 484 \\
\hline
\end{tabular}

Sumber Data :Bagian Kepegawaian Dinas LingkunganKab. Rohil 2015

Berdasarkan tabel 1.1. di atas, diketahui jumlah PNS sebanyak 426 orang dan pegawai honorer berjumlah 484 orang.
Adapun secara spesifik penelitian ini bertujuan untuk untuk mengetahui pengaruh gaji dan pengawasan pimpinan secara parsial dan simultan terhadap 
semangat kerja pegawai honor pada kantor dinas di lingkungan Kabupaten Rokan Hilir.

\section{LANDASAN TEORI}

\subsection{Pengertian Semangat Kerja}

Menurut Koontz (1990) dalam Hasibuan (2009) menyatakan semangat kerja mencerminkan hasrat, kesungguhan dan intensitas dalam pelaksanaan pekerjaan. Sedangkan menurut Hasibuan (2009) manyatakan semangat kerja yaitu keinginan dan kesungguhan seseorang mengerjakan pekerjaannya dengan baik serta disiplin untuk mencapai prestasi kerja yang baik.

Dengan demikian dari pendapat tersebut disimpulkan bahwa semangat kerja merupakan suatu bentuk hasrat dan intensitas yang ditunjukkan oleh pekerjaan atau merupakan keinginan dan kesungguhan pekerja dalam mengerjakan pekerjaan dengan baik (motivasi).

\subsection{Faktor-faktor yang Mempengaruhi} Semangat Kerja Pegawai

\section{Gambar.1}

Kerangka Pemikiran Penelitian

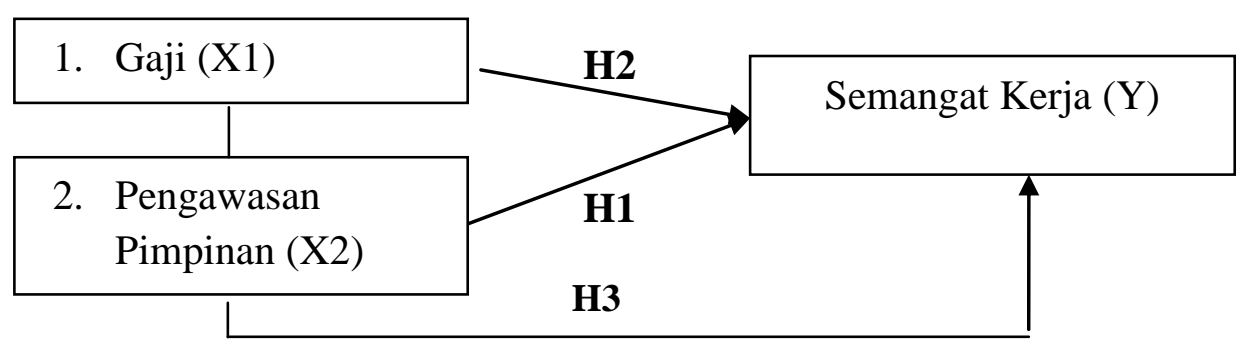

Sumber : Data olahan penelitian

Berdasarkan gambaran kerangka pemikiran di atas dapat ditarik hipotesis penelitian sebagai berikut :

H1 : Diduga gaji berpengaruh secara parsial terhadap semangat kerja pegawai honor pada kantor dinas di lingkungan Kabupaten Rokan Hilir.

$\mathrm{H} 2$ : Diduga pengawasan pimpinan berpengaruh secara parsial terhadap semangat kerja pegawai honor pada kantor dinas di lingkungan Kabupaten Rokan Hilir.
Nawawi (1990) mengatakan bahwa faktor yang mempengaruhi semangat kerja pegawai antara lain sebagai berikut :

1. Minat seseorang terhadap pekerjaan yang dilakukan.

Seseorang yang berminat dalam pekerjaannya akan dapat meningkatkan semangat kerja.

2. Faktor gaji atau upah tinggi akan meningkatkan semangat kerja seseorang

3. Status sosial pekerjaan.

Pekerjaan yang memiliki status sosial yang tinggi danmemberi posisi yang tinggi dapat menjadi faktor penentu meningkatnya semangatkerja.

4. Suasana kerja dan hubungan dalam pekerjaan.

Penerimaan dan penghargaan dapat meningkatkan semangat kerja.

5. Tujuan pekerjaan.

Tujuan yang mulia dapat mendorong semangat kerja seseorangja

6. Hubungan manusiawi 
sampling.Selanjutnya data diperoleh melalui observasi yang dilakukan peneliti pada kantor dinas dilingkungan Pemerintah Kabupaten Rokan Hilir. Kemudian data juga diperoleh dari kuisioner yang peneliti sebarkan pada pegawai honorer disetiap dinas dan badan dilingkungan pemerintah Kabupaten Rokan Hilir.

Setelah data diperoleh, selanjutnya peneliti melakukan proses pengolahan data, menggunakan alat bantu komputer dengan program komputer statistik Statistical program Social Science (SPSS) yang dirasa dapat memberikan hasil yang cukup akurat dan valid.Uji hipotesis dalam penelitian ini adalah Multiple regression atau regresi berganda. Adapaun bentuk model yang digunakan adalah sebagai berikut :

$$
\begin{aligned}
& \mathrm{Y}=\alpha+\beta_{1} \mathrm{X}_{1}+\beta_{2} \mathrm{X}_{2}+\mathrm{E} \\
& \text { Keterangan : } \\
& Y \quad=\text { Semangat Kerja } \\
& \alpha=\text { Konstanta } \\
& \mathrm{X}_{1} \quad=\text { Gaji } \\
& \mathrm{X}_{2} \quad=\text { Pengawasan Pimpinan } \\
& \beta_{1}-\beta_{3} \quad=\text { Koefisien Regresi } \\
& \mathrm{E} \quad=\text { Error term (kesalahan }
\end{aligned}
$$

Penganggu)

Uji f digunakan untuk menguji dan melihat keberadaan pengaruh dari seluruh variabel bebas secara bersama-sama terhadap variabel terikat dalam penelitian ini. Tingkat signifikan yang digunakan adalah 0,05 angka ini lazim digunakan dalam penelitian-penelitian sosial. Untuk melihat tingkat pengaruh variabel bebas dengan variabel terikat dilihat apabila
$\mathrm{F}_{\text {hitung }}$ lebih besar dari $\mathrm{F}_{\text {tabel }}\left(\mathrm{F}_{\text {hitung }}>\mathrm{F}_{\text {tabel }}\right)$ maka terdapat pengaruh variabel bebas terhadap variabel terikat. Namun sebaliknya bila $\mathrm{F}_{\text {hitung }}$ lebih kecil dari $\mathrm{F}_{\text {tabel }}$ $\left(\mathrm{F}_{\text {hitung }}<\mathrm{F}_{\text {tabel }}\right)$ maka tidak terdapat pengaruh variabel bebas terhadap variabel terikat.

Uji $\mathrm{t}$ dilakukan untuk melihat pengaruh dari semua variabel bebas secara parsial (individu) terhadap variabel terikat. Cara mengujinya adalah dengan membandingkan nilai $\mathrm{t}$ hitungdan $\mathrm{t}$ tabel dengan ketentuan bila $t$ hitunglebih besar dari $t_{\text {tabel }}\left(t_{\text {hitung }}>t_{\text {tabel }}\right)$ maka terdapat pengaruh variabel bebas terhadap variabel terikat. Namun sebaliknya bila $\mathrm{t}$ hitung lebih kecil dari $\mathrm{t}$ tabel $\left(\mathrm{t}_{\text {hitung }}<\mathrm{t}_{\text {tabel }}\right)$ maka tidak terdapat pengaruh variabel bebas terhadap variabel terikat, hipotesis uji pengaruh diatas menggunakan uji-t statistik dua sisi. Dalam hal ini tingkat kepercayaan yang dipakai adalah sebesar 5\%.

\section{HASIL DAN PEMBAHASAN}

Berdasarkan pengujian validitas dari 5 (lima) item pernyataan gaji dapat dilihat dari perbandingan Corrected Item-Total Correlation $\mathrm{r}$ hitung lebih besar dari $\mathrm{r}$ tabel $=0,2133$ sehingga dikatakan valid. Selanjutnya, uji realibilitas adalah sebesar 0,893 nilai tersebut lebih besar dari 0,6 sehingga dapat dikatakan bahwa item pernyataan kuesioner yang dibuat sangat baik dijadikan sebagai alat penelitian untuk mengukur gaji pegawai karena tingkat keakuratan sebesar 89,30\%.

\section{Tabel. 4.1}

Rekapitulasi Nilai Rata-rata Item Pernyataan Gaji

\begin{tabular}{|c|c|c|c|r|}
\hline Item & N & Minimu & Maksimu & Rata-rata \\
\hline Gaji 1 & 221 & 1 & 4 & 2.30 \\
\hline Gaji 2 & 221 & 1 & 4 & 2.43 \\
\hline Gaji 3 & 221 & 1 & 4 & 2.63 \\
\hline Gaji 4 & 221 & 1 & 5 & 2.63 \\
\hline Gaji 5 & 221 & 1 & 4 & 2.60 \\
\hline \multicolumn{5}{|c|}{ GAJI }
\end{tabular}

Sumber : Data Olahan Penelitian 2015

Secara umum gaji yang diperoleh oleh pegawai honor pada kantor dinas di lingkungan Kabupaten Rokan Hilir dengan nilai rata-rata sebesar 2,52, dari 5 (lima) item pertanyaan tersebut bahwa nilai ratarata 3 (tiga) yang tertinggi secara berurutan 
yaitu Gaji 3, Gaji 4, dan Gaji 5.

Berdasarkan pengujian validitas dari 5 (lima) item pernyataanpengawasan pimpinan dapat dilihat dari perbandingan Corrected Item-Total Correlation $\mathrm{r}$ hitung lebih besar dari $r$ table $=0,2133$ sehingga dikatakan valid. Selanjutnya, uji realibilitas adalah sebesar 0,786 nilai tersebut lebih besar dari 0,6 sehingga dapat dikatakan bahwa item pernyataan kuesioner yang dibuat cukup baik dijadikan sebagai alat penelitian untuk mengukur motivasi kerja karena tingkat keakuratan sebesar $78,6 \%$.

Tabel. 4.2

Rekapitulasi Nilai Rata-rata Item Pernyataan Pengawasan Pimpinan

\begin{tabular}{|c|c|c|c|c|}
\hline Item & N & Minimum & Maksimu & Rata-rata \\
\hline PP1 & 83 & 1 & 5 & 3,92 \\
\hline PP2 & 83 & 2 & 5 & 4,11 \\
\hline PP3 & 83 & 3 & 5 & 4,10 \\
\hline PP4 & 83 & 3 & 5 & 4,22 \\
\hline PP5 & 83 & 3 & 5 & 4,17 \\
\hline \multicolumn{5}{|r|}{ PENGAWASAN PIMPINAN } \\
\hline
\end{tabular}

Sumber : Data Olahan Penelitian 2015

Secara umum pengawasan pimpinan yang telah dilakukan oleh pimpinan padakantor dinas di Kabupaten Rokan Hilir terhadap pegawai honor berkategori baik dengan nilai sebesar 4,10. Berdasarkan dari 5 (lima) item pertanyaan tersebut bahwa nilai rata-rata 3 (tiga) yang tertinggi secara berurutan yaitu PP2, PP5 dan PP4.

Berdasarkan pengujian validitas dari 5 (lima) item pertanyaansemangat kerja dapat dilihat dari perbandingan Corrected Item-Total Correlation $\mathrm{r}$ hitung lebih besar dari $\mathrm{r}$ table $=0,2133$ sehingga dikatakan valid. Selanjutnya, uji realibilitas adalah sebesar 0,829 nilai tersebut lebih besar dari
0,6 sehingga dapat dikatakan bahwa item pernyataan kuesioner yang dibuat baik dijadikan sebagai alat penelitian untuk mengukur semangat kerja karena tingkat keakuratan sebesar $82,9 \%$.

Tabel. 4.3

Rekapitulasi Nilai Rata-rata Item Pernyataan Semangat Kerja

\begin{tabular}{|c|c|c|c|c|}
\hline Item & N & Minimum & Maksimum & Rata-rata \\
\hline SK1 & 83 & 1 & 5 & 4,07 \\
\hline SK2 & 83 & 1 & 5 & 4,11 \\
\hline SK3 & 83 & 2 & 5 & 4,17 \\
\hline SK4 & 83 & 2 & 5 & 4,25 \\
\hline SK5 & 83 & 1 & 5 & 4,13 \\
\hline \multicolumn{5}{|c|}{ SEMANGAT KERJA } \\
\hline
\end{tabular}

Sumber : Data Olahan Penelitian 2015 
Secara umum semangat kerja yang dimiliki pegawai honor pada kantor dinas di lingkungan Kabupaten Rokan Hilir berkategori baik dengan nilai sebesar 4,15. Berdasarkan dari 5 (lima) item pertanyaan tersebut bahwa nilai rata-rata 3 (tiga) yang tertinggi secara berurutan yaitu SK5, SK3 dan SK4.

\subsection{Uji Asumsi Klasik \\ 4.1.1. Uji Normalitas}

Uji ini dapat dilihat dari normal probabilityplot yang membandingkan distribusi kumulatif dengan distribusi normal.

\section{Gambar 4.1}

Distribusi Normal Data

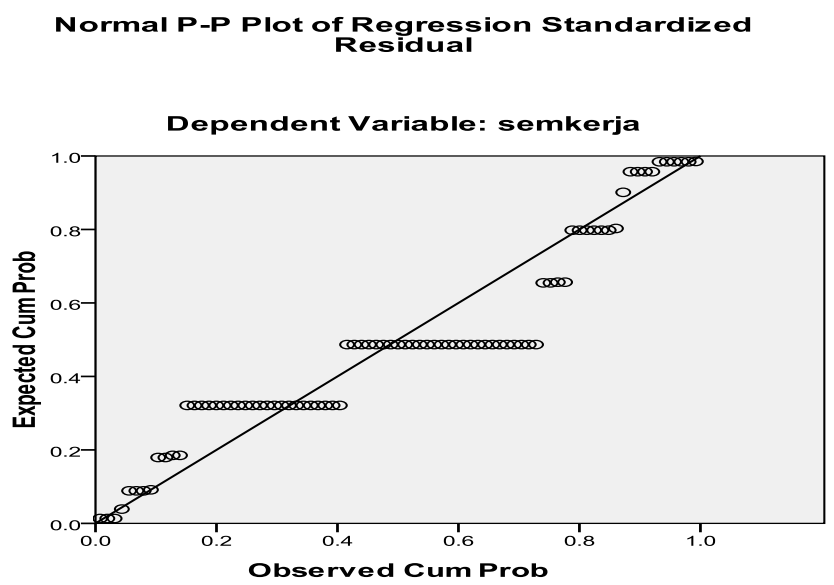

Pada gambar grafik di atas dapat terlihat bahwa data tidak menyebar disekitar garis diagonal serta mengikuti arah garis diagonal. Ini menunjukkan pola distribusi tidak normal, maka dapat disimpulkan bahwa model regresinya tidak memenuhi asumsi

normalitas(Ghozali:2001:112).

\subsubsection{Uji Multikolinieritas}

Secara Umum multikolinieritas jarang dijumpai pada variabel independen hal ini bisa dilihat pada tabel 4.7 hasil pengolahan regresi di bawah ini:

Tabel 4.4

Multikolinieritas

\begin{tabular}{|l|r|r|}
\hline \multirow{2}{*}{\multicolumn{1}{|c|}{ Model }} & \multicolumn{2}{c|}{ Collinearity Statistics } \\
\cline { 2 - 3 } & Tolerance & \multicolumn{1}{c|}{ VIF } \\
\hline Constanta & & \\
\hline Gaji & .957 & 1.045 \\
\hline Pengawasan Pimpinan & .957 & 1.045 \\
\hline
\end{tabular}

Sumber : Data Olahan Penelitian 2015

Dari tabel di atas tersebut menjelaskan bahwa data penelitian ini bebas multikolinieritas terbukti dengan nilai variance inflation factor (VIF) di bawah 10 (Imam Ghozali, 2001). Jadi, dapat disimpulkan bahwa tidak ada multikolinieritas dalam penelitian ini.
4.1.3. Uji Autokorelasi

Tabel 4.5

Model Summary

\begin{tabular}{|r|r|}
\hline Model & Durbin - Watson \\
\hline 1 & 2.141 \\
\hline
\end{tabular}

Sumber : Data Olahan Penelitian 2015 
Dari tabel di atas tersebut terbukti bahwa bilai Durbin Watson (DW) tidak berada antara batas $\mathrm{dl}$ - du pada tingkat signifikan $5 \%$, dengan jumlah sampel 83 dan jumlah variabel bebas 2 (Gujarati, 1997). Diketahui dari tabel Durbin Watson bahwa nilai batas atas $\mathrm{dl}=1,586 \mathrm{dan} \mathrm{du}=$ 1,688 dibawah nilai Durbin Watson untuk model pengujian pengaruh pemahaman konsep keagamaan, motivasi dan penilaian prestasi kerja 2,141. Jadi, dapat disimpulkan bahwa tidak ada autokorelasi dalam penelitian ini.

\subsubsection{Uji Heteroskedastisitas}

Untuk mengetahui adanya kondisi heterokedastisitas pada data penelitian dapat dilihat pada grafik scatterplot yang ada pada lampiran dan terbukti bahwa semua titik menyebar diatas maupun dibawah angka 0 sumbu $\mathrm{Y}$.

\subsection{Pengujian Hipotesis}

\subsubsection{Pengaruh Secara Bersama-sama (simultan)}

Variabel Gaji (XI), Pengawasan Pimpinan (X2), secara simultan (bersama-sama) berpengaruh terhadap semangat kerja pegawai honor pada kantor dinas di lingkungan Kabupaten Rokan Hilir (Y) dengan nilai $\mathrm{R}^{2}$ sebesar 0,224 atau $22,4 \%$ dan sisanya $77,6 \%$ yang tidak diteliti dalam penelitian ini.

Selajutnya, uji keputusan ini secara simultan apakah signifikan atau tidak dapat dibuktikan dengan nilai $\mathrm{F}$ hitung sebesar 11,575dengan tingkat signifikan sebesar $0,00<0,05$, hal ini menunjukkan bahwa secara simultan berpengaruh terhadap semangat kerja pegawai sehingga $\mathrm{Ha}$ diterima dan Ho ditolak.

\subsubsection{Pengaruh Secara Parsial (sendiri- sendiri)}

Berdasarkan hasil pengolahan data menggunakan program SPSS pada standardized koefisien regresi pada program statistik SPSS, yaitu:

1. Pengaruh Gaji $\left(X_{1}\right)$ terhadap semangat kerja (Y) adalah 0,198

2. Pengaruh pengawasan pimpinan $\left(X_{2}\right)$ terhadap semangat kerja pegawai (Y) adalah 0,405

Untuk mengetahui apakah terdapat pengaruh yang signifikan atau tidak secara simultan dilakukan dengan uji t statistik padaalpha $=0,05(5 \%)$ yang dijelaskan pada tabel 4.9 di bawah ini:

Tabel 4.9.

\section{Coefficients $^{\mathrm{a}}$}

\begin{tabular}{|c|c|c|c|c|c|}
\hline \multirow[t]{2}{*}{ Model } & \multicolumn{2}{|c|}{$\begin{array}{l}\text { Unstandardized } \\
\text { Coefficients }\end{array}$} & \multirow{2}{*}{\begin{tabular}{|c}
$\begin{array}{c}\text { Standardi } \\
\text { zed } \\
\text { Coefficie } \\
\text { nts }\end{array}$ \\
Beta
\end{tabular}} & \multirow[t]{2}{*}{$\mathrm{T}$} & \multirow[t]{2}{*}{ Sig. } \\
\hline & B & $\begin{array}{l}\text { Std. } \\
\text { Error }\end{array}$ & & & \\
\hline Constanta & 2 & 0.483 & & 4.141 & 0 \\
\hline Gaji & 0.198 & 0.077 & 0.257 & 2.549 & 0.013 \\
\hline $\begin{array}{l}\text { Pengawasan } \\
\text { Pimpinan }\end{array}$ & 0.405 & 0.117 & 0.349 & 3.464 & 0.001 \\
\hline
\end{tabular}

Dependent Variable: SEMANGAT KERJA

Pengaruh gaji (XI) dan pengawasan pimpinan (X2) terhadap semangat kerja pegawai honor pada kantor dinas di lingkungan Kabupaten Rokan Hilir (Y) adalah signifikan dimana signifikansinya lebih kecil dari 0,05 sehingga $\mathrm{H} 0=$ ditolak dan $\mathrm{Ha}=$ diterima.

\section{PENUTUP}

Berdasarkan penelitian maka dapat disimpulkan beberapa hal sebagai berikut:

1. Secara simultan gaji dan pengawasan pimpinan berpengaruh signifikan terhadap semangat pegawai honor sebesar $22,4 \%$. Dan sisanya $77,6 \%$ dipengaruhi oleh variabel lain yang tidak diteliti pda penelitian ini.

2. Pengujian secara parsial diperoleh bahwa terdapat pengaruh antara variabel gaji terhadap semangat kerja pegawai honor adalah sebesar 0,198 atau 19,8 \%dengan tingkat signifikan $0,013<0,05$.

3. Pengujian secara parsial diperoleh bahwa terdapat pengaruh antara variabel pengawasan pimpinan terhadap semangat kerja pegawai adalah sebesar 0,405 atau 40,5 \%dengan tingkat signifikan $0,000<0,05$.

Berdasarkan analisis pembahasan penelitian yang telah diuraikan serta bertitik tolak dari kesimpulan yang dikemukakan maka ada beberapa saran sebagai bahan pertimbangan selanjutnya, 
yaitu:

1. Untuk pegawai, agarbekerja lebih bertanggung jawab, tepat waktu dan selalu berada didalam ruangan kerja saat jam dinas sedang berlangsung.

2. Untuk pimpinan, dari gaji yang telah diberikan kepada pegawai honor sebaiknya ada pertimbangan untuk meningkatkan jumlah gaji yang diberikan dan disesuaikan dengan UMR yang berlaku, dan dari pengawasan sebaiknya pimpinan menekankan kembali fungsi-fungsi dari pengawasan sehingga pegawai memiliki kinerja yang lebih baik lagi serta penekanan pada pemberlakuan sanksi kepada pegawai yang melanggar aturan yang berlaku.

\section{DAFTAR PUSTAKA}

Bungin, Burhan. 2005. Metode Penelitian Kuantitatif. Jakarta : Penerbit Prenada Media.

Ghozali, Imam. 2005.Aplikasi Analisis Multivariate Dengan Program SPSS. Cetakan IV. Semarang. BP. UNDIP.

Handoko, T. Hani. 2010. Manajemen Personalia dan Sumber Daya Manusia. Yogyakarta: BPFE UGM.

Mathis, Robert L. dan Jackson, John H., 2006. Human Resources Management. Edisi sepuluh, Jakarta : Penerbit Salemba Empat.

Nawawi, Hadari. 1990. Administrasi Personel Untuk Meningkatkan Produktivitas Kerja. Jakarta : Haji Masaagung

Strategik Organisasi Non Profit Bidang Pemerintahan. Gajah Mada University Press. Yogyakarta.

Sastrohadiwiryo. 2008. Semangat Kerja Karyawan untuk Perusahaan. BahanaManajemen

Pendidikan. Jakarta: PT. Indeks Kelompok GRAMEDIA.

Sugiyono. 2007. Metode Penelitian Bisnis. Cetakan Kelima. Edisi Kedua. Bandung : CV. Alfabeta.
Tasmara, Toto. 2002. Membudayakan Etos Kerja Islami. Jakarta. Penerbit : CV. Gema Insani Press.

Hasibuan, Malayu S.P. (2009), Manajemen Sumber Daya Manusia, Edisi Revisi, Cetakan ketiga belas, Jakarta : PT. Bumi Aksara.

Jurnal Administrasi Pendidikan. Hubungan Pengawasan Pimpinan Dengan Semangat Kerja Pegawai Badan Pendidikan dan Pelatihan Provinsi Sumatera Barat. Volume 1 Nomor 1 Oktober 2013. Halaman 43

http://www.e-

jurnal.com/2013/12/pengaruh-

kepemimpinan-dankompensasi.htmldi akses tanggal 1 April 2015.

http://www.e-

jurnal.com/2015/02/pengaruh-

kompensasi-terhadap-

semangat.html di akses tanggal 3 April 2015 